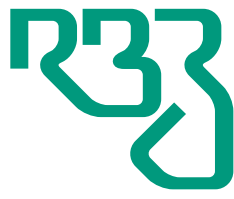

Revista

Brasileira de

Zootecnia

Brazilian Journal of Animal Science

ISSN 1806-9290

www.rbz.org.br

\title{
Multivariate analysis using morphometric and ultrasound information for selection of tilapia (Oreochromis niloticus) breeders
}

\author{
Sheila Nogueira de Oliveira ${ }^{1^{*}}$ (iD), Ricardo Pereira Ribeiro ${ }^{2}$ (iD), Carlos \\ Antonio Lopes de Oliveira $^{2}$ iD, Nelson Mauricio Lopera-Barrero ${ }^{3}$ (iD, \\ Rusbel Raul Aspilcueta Borquis ${ }^{1}$ (iD), Aline Mayra da Silva Oliveira \\ Zardin $^{2}$ (iD), Felipe Pinheiro de Souza ${ }^{3}$ (iD, Angela Rocio Poveda-Parra ${ }^{3}$ \\ ${ }^{1}$ Universidade Federal da Grande Dourados, Dourados, MS, Brasil. \\ ${ }^{2}$ Universidade Estadual de Maringá, Departamento de Zootecnia, Maringá, PR, Brasil. \\ ${ }^{3}$ Universidade Estadual de Londrina, Departamento de Zootecnia, Londrina, PR, Brasil.
}

\author{
*Corresponding author: \\ sheilanoliveira@ufgd.edu.br \\ Received: June 28, 2017 \\ Accepted: September 18, 2018 \\ How to cite: Oliveira, S. N.; Ribeiro, R. P.; \\ Oliveira, C. A. L.; Lopera-Barrero, N. M.; \\ Aspilcueta Borquis, R. R.; Zardin, A. M. S. O.; \\ Souza, F. P. and Poveda-Parra, A. R. 2019. \\ Multivariate analysis using morphometric and \\ ultrasound information selection of tilapia \\ (Oreochromis niloticus) breeders. Revista \\ Brasileira de Zootecnia 48:e20170179. \\ https://doi.org/10.1590/rbz4820170179 \\ Copyright: This is an open access article \\ distributed under the terms of the \\ Creative Commons Attribution License \\ (http://creativecommons.org/licenses/by/4.0/), \\ which permits unrestricted use, distribution, \\ and reproduction in any medium, provided the \\ original work is properly cited.
}

\begin{abstract}
This study evaluated morphometric and ultrasound information of tilapia (O. niloticus) breeders through multivariate analysis. We applied correlation, clustering, and principal component analysis to a dataset composed of information from 222 male and female breeders of the improved GIFT strain. The body weight, objective of the breeding program, showed a high positive correlation with most of the morphometric parameters. The formation of clusters indicated characteristics responsible for muscle composition and carcass weight. Some characteristics showed a high correlation, such as body weight and fillet weight ( 0.98 and 0.94 for females and males, respectively), and a high contribution to the explanation of data variability; of the total characteristics evaluated for females, two explained $75 \%$ data variability and four explained $72 \%$ for males. We concluded that it is possible to reduce the number of characteristics measured, as well as use information of average daily weight gain and body weight to select female and male breeders, respectively, to drive genetic gains favoring more productive generations.
\end{abstract}

Keywords: aquaculture, breeding, fish farming, Oreochromis sp., phenotypic selection

The Brazilian aquaculture production in 2016 was 507.12 million tons, an increase of $4.4 \%$ over the previous year (IBGE, 2016). Tilapia was the most produced fish with 239,09 million tons, corresponding to $47.1 \%$ of all fish produced in Brazil (IBGE, 2016). Projections made for 2030 indicate that there will be a $38.32 \%$ increase in fish production, due to the demand for healthier foods and the improvement in the quality, standardization, and constancy of fish supply in the market (FAO, 2014). In this context, farming fish that present high growth performance under certain conditions should be prioritized, so that the selection of these genetically superior individuals can further maximize productivity and add value to the product (Resende et al., 2010).

The genetic improvement of the animals seeks, among other things, the productive increase of economically important characteristics, such as the body weight of fish. This genetic improvement involves the selection and mating of the animals that present the best performance for the desirable 
trait, which can be directly measured or indirectly measured by means of others that are correlated with it. In the genetic breeding of fish in Brazil, such as Tilapia (Oreochromis niloticus), it is possible to use performance information such as weight, daily weight gain, morphometric measurements (Ribeiro and Legat, 2008), and ultrasound measurements (Bianchecci, 2011).

Some of these measurements have high genetic correlation (Kunita et al. 2013), and when there is a set of correlated variables, it is possible to transform the set of original data into another with uncorrelated variables, which will be derived linear of combinations of the original data, in descending order of importance. These combinations are the first possible variance in the first variables, called principal components (PC; Manly, 2008).

In principal component analysis (PCA), the variance contained in each principal component is expressed by the eigenvalues of the standardized matrix. The largest eigenvalue is associated with the first principal component, the second largest eigenvalue to the second principal component, until the smallest eigenvalue is associated with the last principal component, which places the first as the most important. Thus, the first principal components usually explain much of the variance of the original variables. This statistical tool can be used successfully to support decision-making (Yamaki et al., 2009; Silva and Sbrissia, 2010; Silva et al., 2015) in the choice of variables that effectively contribute to the explanation of the target trait of selection in breeding programs, such as tilapia in Brazil.

Given the above, the present study aimed to evaluate possible associations between morphometry and ultrasound characteristics obtained from tilapia specimens breeders by multivariate analysis.

\section{Material and Methods}

The data set was composed initially of 231 pieces of information of male and female breeders from a genetically improved fish generation (generation 2012/2013), GIFT strain from the Tilapia Breeding Program of the State University of Maringá (State of Paraná, Brazil), and were individualized by microchip, in which animals are selected by the genetic gain presented for growth rate (average daily gain - ADG). The average daily weight gain was obtained by dividing the final body weight (slaughter) by age (in days) of each animal studied.

The ultrasound device used for the measurements was the Digital Palmtop Ultrasound Scanner, version V1.10E-1, Model CUS-3000V (Shenzhen Carewell electronics Co, Shenzhen, China). Fish were killed by the destruction of the spinal cord. After slaughter, the animals were weighed on a precision weighing scale of $0.1 \mathrm{~g}$. For filleting, fish processing was performed manually by the same operator. The filleting procedure followed the order: processing headless fish (dorsal-ventral cut), filleting, and skinning of fillet with knife.

The fish studied were under the same culture conditions, with an average temperature of $22{ }^{\circ} \mathrm{C}$. The measurements of the samples were all obtained in sequence at the time of slaughter.

To standardize the variables and remove the effect of scales, a correlation matrix was used, as suggested by Souza (2000), which presented non-zero correlation coefficients. Performance, morphometric, and ultrasound characteristics were analyzed (Table 1).

Data were adjusted, removing nine pieces of information from typing errors, which resulted in 222 pieces of information. Prior to the application of the multivariate analyses, the data were subjected to the KMO (Kaiser-Meyer-Olkin) statistic, with KMO being greater than 0.80 (in males and females), and Bartlett's test was significant. These statistics indicate that data can be analyzed by multivariate analysis.

For the application of multivariate analysis (cluster analysis and PCA), the data set was standardized; each descriptor, thus, had null mean and unit variance. This analysis allowed to reduce the space of original variables into a smaller set, preserving the maximum of the original variability of the data. The results of Pearson's linear correlation were analyzed by the F test, at the $5 \%$ probability level. All statistical analyses were performed in software R 3.2.2 (R Development Core Team, 2008), with the use of vegan packages (Oksanen et al., 2010), using method WARD for the Euclidean Distance (Cruz et al., 2004).

R. Bras. Zootec., 48:e20170179, 2019 
Table 1 - Description of the characteristics used in the study

\begin{tabular}{|c|c|c|}
\hline Variable & Abbreviation & Description \\
\hline Body weight (g) & BW & Measurement on an analytical balance \\
\hline Standard length (cm) & SL & From the anterior end of the head to the beginning of the caudal fin insertion \\
\hline Total length $(\mathrm{cm})$ & $\mathrm{TL}$ & From the anterior end of the head to the end of the caudal fin \\
\hline Height $1(\mathrm{~cm})$ & $\mathrm{H} 1$ & Front height of the first ray of the dorsal fin \\
\hline Width $1(\mathrm{~cm})$ & W1 & Measured from the front of the first ray of the dorsal fin \\
\hline Head size $(\mathrm{cm})$ & HS & $\begin{array}{l}\text { Measured between the anterior end of the head and the caudal border of } \\
\text { the operculum }\end{array}$ \\
\hline Height $2(\mathrm{~cm})$ & $\mathrm{H} 2$ & Height between the final insertion of the anal and dorsal fins \\
\hline Width $2(\mathrm{~cm})$ & W2 & Width between the final insertion of the anal and dorsal fins \\
\hline Ultrasound height $1(\mathrm{~mm})$ & UH1 & $\begin{array}{l}\text { Left side area of the base of the insertion of the pelvic fin to the anterior } \\
\text { base of the dorsal fin }\end{array}$ \\
\hline Ultrasound width 1 (mm) & UW1 & $\begin{array}{l}\text { Width from the base of the insertion of the pelvic fin to the anterior base } \\
\text { of the dorsal fin }\end{array}$ \\
\hline Ultrasound area $1\left(\mathrm{~mm}^{2}\right)$ & UA1 & $\begin{array}{l}\text { Height from the base of the insertion of the pelvic fin to the anterior base } \\
\text { of the dorsal fin }\end{array}$ \\
\hline Ultrasound height $2(\mathrm{~mm})$ & UH2 & Left side area between the final insertion of the anal and dorsal fins \\
\hline Ultrasound width 2 (mm) & UW2 & Width between the final insertion of the anal and dorsal fins \\
\hline Ultrasound area $2\left(\mathrm{~mm}^{2}\right)$ & UA2 & Height between the final insertion of the anal and dorsal fins \\
\hline Fillet weight (g) & FW & $\begin{array}{l}\text { Final fillet weight, after filleting procedure; measured on an analytical } \\
\text { balance }\end{array}$ \\
\hline Fillet yield (\%) & FY & Ratio between fillet weight and fish weight \\
\hline Average daily gain (g) & ADG & Rate of weight gain per day (final body weight/age) \\
\hline
\end{tabular}

\section{Results}

The descriptive statistics of the characteristics (Table 2) show that males presented higher values for all the characteristics studied, such as average weight $(1551.0 \mathrm{~g})$ in relation to females $(761.0 \mathrm{~g})$, with only one exception, the characteristic ultrasound height 1 (UH1), to which, in this case, the opposite occurs.

Table 2 - Mean, maximum, and minimum values for morphometric and ultrasound measurements for males and females

\begin{tabular}{|c|c|c|c|c|c|c|}
\hline \multirow{2}{*}{ Variable } & \multicolumn{3}{|c|}{ Females } & \multicolumn{3}{|c|}{ Males } \\
\hline & Mean & Min - max & SD & Mean & Min - max & SD \\
\hline Body weight (g) & 761.0 & $668-1,245$ & 196.45 & 1551 & $894-1,875$ & 281.61 \\
\hline Standard length $(\mathrm{cm})$ & 27.49 & $24.7-36.5$ & 1.84 & 33.47 & $28-38$ & 1.91 \\
\hline Total length (cm) & 34.35 & $31-42.9$ & 2.09 & 42.21 & $36-47$ & 2.19 \\
\hline Height $1(\mathrm{~cm})$ & 10.34 & $7.2-15.7$ & 1.00 & 13.41 & $8.10-16.30$ & 1.31 \\
\hline Width $1(\mathrm{~cm})$ & 4.53 & $3.4-5.4$ & 0.22 & 5.07 & $5-7$ & 0.22 \\
\hline Head size $(\mathrm{cm})$ & 8.99 & $7.1-11.2$ & 0.61 & 10.69 & $7.2-12$ & 0.83 \\
\hline Height 2 (cm) & 3.70 & $3.7-6.8$ & 0.38 & 5.03 & $4.7-7$ & 0.41 \\
\hline Width $2(\mathrm{~cm})$ & 1.73 & $1.1-2.7$ & 0.19 & 2.22 & $1.3-3.6$ & 0.19 \\
\hline Ultrasound area $1\left(\mathrm{~mm}^{2}\right)$ & 20.47 & $18-26$ & 1.59 & 25.73 & $22-32$ & 1.59 \\
\hline Ultrasound width 1 (mm) & 30.75 & $28-39$ & 2.88 & 40.45 & $32-52$ & 2.88 \\
\hline Ultrasound height 1 (mm) & 66.48 & $62-81$ & 3.47 & 63.53 & $60-81$ & 3.47 \\
\hline Ultrasound area $2\left(\mathrm{~mm}^{2}\right)$ & 14.55 & $11-18$ & 1.30 & 18.89 & $18-26$ & 1.30 \\
\hline Ultrasound width 2 (mm) & 38.70 & $31-49$ & 4.03 & 50.25 & $32-60$ & 4.03 \\
\hline Ultrasound height 2 (mm) & 37.38 & $31-46$ & 2.36 & 37.36 & $33-62$ & 2.36 \\
\hline Fillet weight (g) & 257.10 & $189-481$ & 72.15 & 543.40 & $290-870$ & 113.35 \\
\hline Fillet yield (\%) & 33.15 & $0.28-0.38$ & 1.26 & 34.93 & $0.32-0.47$ & 2.70 \\
\hline Average daily gain (g) & 1.57 & $1.04-3.19$ & 0.38 & 3.53 & $2.09-4.76$ & 0.56 \\
\hline
\end{tabular}

SD - standard deviation. 
In cluster analysis for females (Figure 1), three main groups were formed: the first group, UH1 and ultrasound height 2 (UH2); the second group, fillet yield (FY); and the third group formed by the other characteristics in the study. For males, two groups were found: one consisting of UH2, FY, and UH1 and the other, of the other parameters.

The results for the principal components (Table 3) show that, for females, $75 \%$ of the variation is explained considering two PC; in turn, for males, $72 \%$ variation can be explained considering four components. Some characteristics presented similar values of the total variation, as observed in the first principal component (PC1) for females, in which the characteristics of body weight (BW), fillet weight (FW), and ADG have the same magnitude (0.29), as well as height 1 (H1), width 2 (W2), ultrasound area 1 (UA1), ultrasound width 1 (UW1), ultrasound width 2 (UW2), and total length (TL) (0.27). A similar trend was found for males with close values in PC1 for BW (0.31) and FW (0.30) and the same for standard length (SL), H1, UW1, UW2, and TL (0.28). For females, important characteristics as UH1, UH2, and FY showed magnitude of $-0.06,-0.08$, and 0.13 , respectively, and these characteristics for males showed a magnitude of $0.11,0.06$, and 0.01 , respectively (Table 3). The spatial projection of the vectors of the studied variables, considering two main components for females and for males is shown in Figure 2.

The study of Pearson's correlation coefficient showed a correlation between the morphometric measurements (Table 4). Some characteristics presented a moderate correlation, such as 0.55 between FY and FW (females) and others showed a low correlation, such as 0.03 between BW and UH1 (males), indicating that these characteristics act independently, that is, the selection of one does not influence the selection of the other, unlike strongly correlated characteristics such as ADG and BW of 0.99 in females. Low correlation may also indicate that some characteristics are orthogonal, that is, they are not in the same component and may be in another of smaller magnitude. Other characteristics presented a negative correlation, indicating that the impact of the selection performed may act differently in each one, while one suffers increase, another may suffer reduction, such as -0.25 between BW and UH1 in females.

For females (Table 4), some parameters such as BW, FW, and ADG showed a high correlation (above 0.95). In the same way, males presented the same parameters with correlation above 0.89 . Fillet yield is a trait with significant economic impact and presented the highest correlation with fillet weight (FW) in both females (0.55) and males (0.60), and a weaker correlation with width 1 (W1) and UH1 (females - 0.03 and 0.05 ) and also head size (HS) and UH2 (males -0.03 and 0.08); studies to select fish with higher FY may contribute to the improvement of performance of this trait.
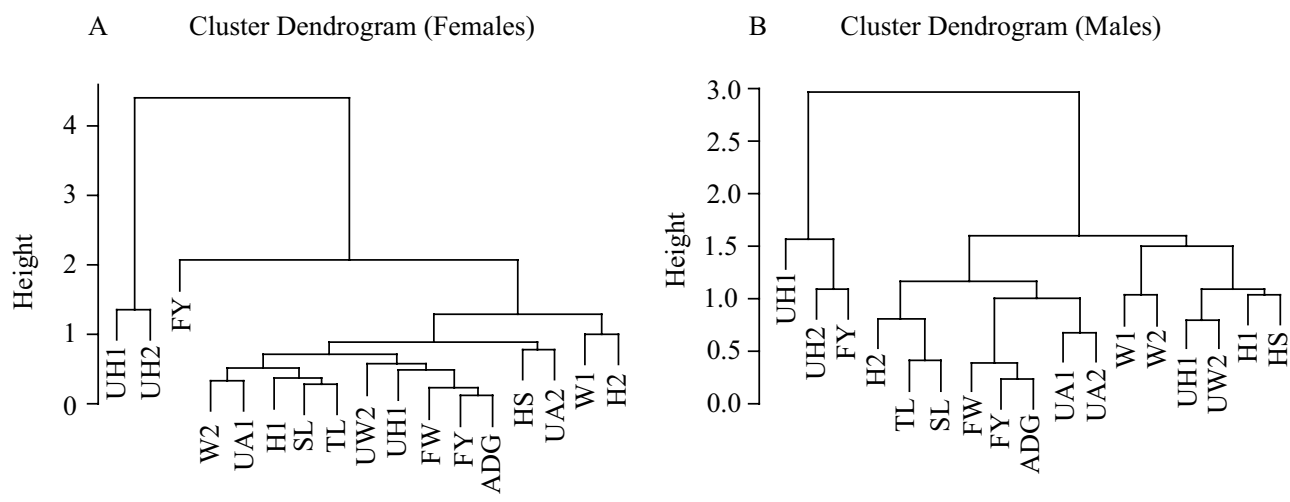

BW - body weight; SL - standard length; H1 - height 1; W1 - width 1; HS - head size; H2 - height 2; W2 - width 2; UA1 - ultrasound area 1; UW1 - ultrasound width 1; UH1 - ultrasound height 1; UA2 - ultrasound area 2; UW2 - ultrasound width 2; UH2 - ultrasound height 2; TL - total length; FW - fillet weight; FY - fillet yield; ADG - average daily gain.

Figure 1 - Dendrogram between the characteristics of females (A) and males (B).

R. Bras. Zootec., 48:e20170179, 2019 
Table 3 - Principal components (PC), eigenvalues ( $\chi$ ), percentage of variance explained by components (VCP), and cumulative variance (VCPA) in morphometric and ultrasound variables

\begin{tabular}{|c|c|c|c|c|c|c|c|c|}
\hline \multirow{2}{*}{ PC } & \multicolumn{4}{|c|}{ Females } & \multicolumn{4}{|c|}{ Males } \\
\hline & PC1 & PC2 & PC3 & PC4 & PC1 & PC2 & PC3 & PC4 \\
\hline BW & 0.29 & 0.04 & 0.03 & 0.01 & 0.31 & 0.05 & -0.07 & 0.10 \\
\hline SL & 0.28 & -0.08 & 0.06 & -0.06 & 0.28 & 0.07 & -0.29 & 0.10 \\
\hline H1 & 0.27 & -0.08 & -0.08 & 0.05 & 0.28 & 0.11 & -0.12 & 0.12 \\
\hline W1 & 0.20 & -0.21 & -0.18 & -0.57 & 0.19 & 0.18 & -0.24 & -0.39 \\
\hline HS & 0.24 & 0.08 & 0.16 & -0.09 & 0.27 & -0.08 & -0.13 & -0.21 \\
\hline $\mathrm{H} 2$ & 0.20 & -0.21 & -0.28 & -0.19 & 0.23 & 0.27 & 0.06 & 0.02 \\
\hline W2 & 0.27 & -0.10 & 0.01 & 0.12 & 0.25 & 0.03 & -0.20 & 0.08 \\
\hline UA1 & 0.27 & 0.13 & -0.13 & -0.13 & 0.25 & -0.28 & -0.25 & -0.06 \\
\hline UW1 & 0.27 & 0.24 & -0.17 & -0.02 & 0.28 & -0.17 & 0.26 & -0.09 \\
\hline UH1 & -0.06 & -0.59 & 0.49 & 0.20 & 0.11 & 0.51 & 0.06 & 0.21 \\
\hline UA2 & 0.26 & 0.23 & -0.12 & -0.23 & 0.27 & -0.25 & -0.08 & -0.03 \\
\hline UW2 & 0.27 & 0.14 & -0.20 & 0.01 & 0.28 & -0.19 & 0.10 & -0.15 \\
\hline $\mathrm{UH} 2$ & -0.08 & -0.55 & 0.49 & -0.36 & 0.06 & 0.52 & 0.26 & -0.26 \\
\hline TL & 0.27 & 0.03 & -0.17 & 0.07 & 0.28 & -0.03 & -0.26 & 0.10 \\
\hline FW & 0.29 & -0.02 & -0.12 & -0.09 & 0.30 & -0.16 & 0.15 & 0.11 \\
\hline FY & 0.13 & -0.29 & -0.48 & -0.60 & 0.01 & -0.32 & 0.68 & 0.01 \\
\hline ADG & 0.29 & 0.09 & 0.07 & 0.03 & 0.18 & 0.01 & -0.00 & 0.77 \\
\hline$\lambda$ & 3.35 & 1.26 & 1.06 & 0.99 & 2.79 & 1.59 & 1.02 & 0.96 \\
\hline VCP & 0.66 & 0.09 & 0.06 & 0.05 & 0.46 & 0.15 & 0.06 & 0.05 \\
\hline VCPA & 0.66 & 0.75 & 0.82 & 0.87 & 0.46 & 0.61 & 0.67 & 0.72 \\
\hline
\end{tabular}

BW - body weight; SL - standard length; H1 - height 1; W1 - width 1; HS - head size; H2 - height 2; W2 - width 2; UA1 - ultrasound area 1; UW1 - ultrasound width 1; UH1 - ultrasound height 1; UA2 - ultrasound area 2; UW2 - ultrasound width 2; UH2 - ultrasound height 2; TL - total length; FW - fillet weight; FY - fillet yield; ADG - average daily gain.
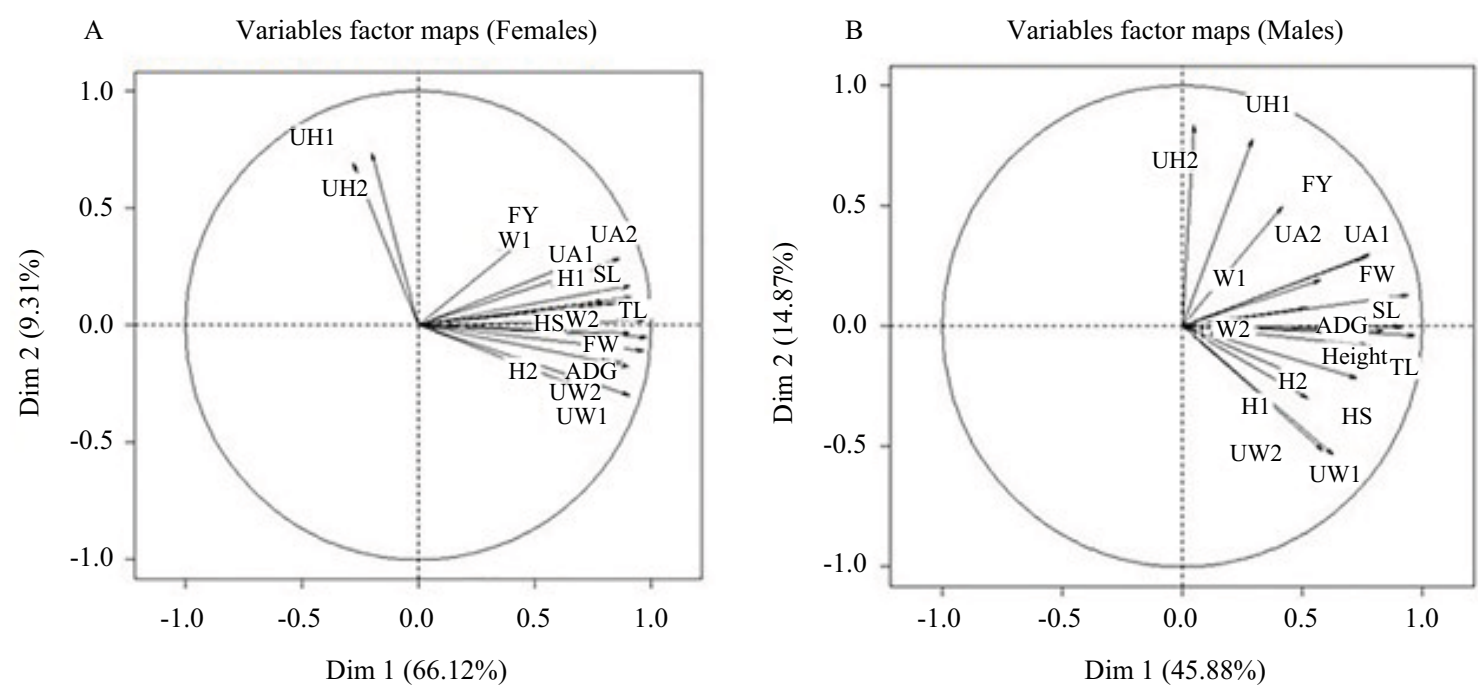

BW - body weight; SL - standard length; H1 - height 1; W1 - width 1; HS - head size; H2 - height 2; W2 - width 2; UA1 - ultrasound area 1; UW1 - ultrasound width 1; UH1 - ultrasound height 1; UA2 - ultrasound area 2; UW2 - ultrasound width 2; UH2 - ultrasound height 2; TL - total length; FW - fillet weight; FY - fillet yield; ADG - average daily gain.

Figure 2 - Spatial projection of the vectors of the studied variables, considering two principal components (DIM1 = PC1 and DIM2 = PC2), for females (A) and males (B). 
Table 4 - Correlation between morphometric and ultrasound measurements for females (above the main diagonal) and for males (below diagonal)

\begin{tabular}{lccccccccccccccccc}
\hline & BW & SL & H1 & W1 & HS & H2 & W2 & UA1 & UW1 & UH1 & UA2 & UH2 & UW2 & TL & FW & FY & ADG \\
\hline BW & 1 & 0.94 & 0.84 & 0.63 & 0.73 & 0.65 & 0.89 & 0.87 & 0.91 & -0.25 & 0.83 & 0.87 & -0.28 & 0.90 & 0.98 & 0.41 & 0.99 \\
SL & 0.84 & 1 & 0.83 & 0.64 & 0.74 & 0.55 & 0.86 & 0.82 & 0.77 & -0.11 & 0.81 & 0.79 & -0.16 & 0.94 & 0.91 & 0.34 & 0.92 \\
H1 & 0.49 & 0.39 & 1 & 0.59 & 0.88 & 0.54 & 0.80 & 0.79 & 0.75 & -0.10 & 0.79 & 0.80 & -0.22 & 0.84 & 0.82 & 0.41 & 0.83 \\
W1 & 0.53 & 0.38 & 0.21 & 1 & 0.56 & 0.48 & 0.60 & 0.63 & 0.53 & 0.06 & 0.72 & 0.59 & 0.04 & 0.54 & 0.59 & 0.03 & 0.60 \\
HS & 0.49 & 0.47 & 0.28 & 0.24 & 1 & 0.32 & 0.73 & 0.67 & 0.65 & -0.12 & 0.62 & 0.65 & -0.21 & 0.81 & 0.72 & 0.35 & 0.70 \\
H2 & 0.67 & 0.56 & 0.40 & 0.38 & 0.37 & 1 & 0.53 & 0.58 & 0.72 & -0.36 & 0.60 & 0.65 & -0.24 & 0.50 & 0.64 & 0.31 & 0.69 \\
W2 & 0.48 & 0.38 & 0.24 & 0.32 & 0.26 & 0.36 & 1 & 0.87 & 0.80 & -0.09 & 0.76 & 0.77 & -0.21 & 0.87 & 0.89 & 0.49 & 0.86 \\
UA1 & 0.72 & 0.53 & 0.38 & 0.52 & 0.27 & 0.45 & 0.37 & 1 & 0.81 & 0.10 & 0.79 & 0.84 & -0.28 & 0.78 & 0.87 & 0.47 & 0.83 \\
UW1 & 0.58 & 0.43 & 0.40 & 0.22 & 0.38 & 0.51 & 0.28 & 0.48 & 1 & -0.50 & 0.73 & 0.84 & -0.36 & 0.76 & 0.89 & 0.38 & 0.91 \\
UH1 & 0.03 & 0.01 & -0.08 & 0.24 & -0.15 & -0.11 & 0.05 & 0.41 & -0.59 & 1 & -0.05 & -0.15 & 0.18 & -0.16 & -0.22 & 0.05 & -0.31 \\
UA2 & 0.66 & 0.54 & 0.30 & 0.46 & 0.27 & 0.38 & 0.36 & 0.63 & 0.38 & 0.15 & 1 & 0.79 & 0.09 & 0.68 & 0.82 & 0.42 & 0.82 \\
UH2 & 0.55 & 0.38 & 0.37 & 0.30 & 0.36 & 0.45 & 0.21 & 0.35 & 0.56 & -0.29 & 0.49 & 1 & -0.53 & 0.77 & 0.83 & 0.26 & 0.87 \\
UW2 & 0.22 & 0.26 & 0.00 & 0.22 & 0.01 & 0.03 & 0.21 & 0.37 & -0.09 & 0.45 & 0.56 & -0.40 & 1 & -0.34 & -0.22 & 0.14 & -0.29 \\
TL & 0.75 & 0.81 & 0.37 & 0.35 & 0.40 & 0.65 & 0.30 & 0.47 & 0.39 & 0.01 & 0.43 & 0.36 & 0.16 & 1 & 0.86 & 0.30 & 0.88 \\
FW & 0.94 & 0.78 & 0.44 & 0.49 & 0.41 & 0.62 & 0.46 & 0.74 & 0.51 & 0.12 & 0.70 & 0.48 & 0.31 & 0.63 & 1 & 0.55 & 0.97 \\
FY & 0.32 & 0.25 & 0.06 & 0.15 & -0.03 & 0.22 & 0.19 & 0.41 & 0.09 & 0.27 & 0.47 & 0.08 & 0.42 & 0.17 & 0.60 & 1 & 0.39 \\
ADG & 0.93 & 0.79 & 0.46 & 0.47 & 0.43 & 0.60 & 0.39 & 0.53 & 0.53 & 0.05 & 0.50 & 0.50 & 0.23 & 0.71 & 0.89 & 0.35 & 1 \\
\hline
\end{tabular}

BW - body weight; SL - standard length; H1 - height 1; W1 - width 1; HS - head size; H2 - height 2; W2 - width 2; UA1 - ultrasound area 1; UW1 - ultrasound width 1; UH1 - ultrasound height 1; UA2 - ultrasound area 2; UW2 - ultrasound width 2; UH2 - ultrasound height 2; TL - total length; FW - fillet weight; FY - fillet yield; ADG - average daily gain.

\section{Discussion}

The formation of the cluster composed of UH1 (height near the head), UH2 (caudal peduncle height), and FY indicates that these characteristics are related to the muscular composition of fish, while the other characteristics of the study are related to carcass weight. The FY trait is a separate component, corroborating its differentiation from the other characteristics, since it depends on some biological factors such as the anatomical shape of the animal and the presence or absence of intramuscular bones, head size, and number of viscera (Adames et al., 2014). A 1993 study (Eyo, 1993) found that fillet yield is influenced by anatomical shape and that large-headed fish exhibit lower fillet yields when compared with small-headed fish, and that other human or mechanical factors also interfere with fish yield (Pinheiro et al., 2006). It also depends on the filleting method (Bombardelli and Sanches, 2008) and type of cut for removal of the head, skin, and fins (Macedo-Viégas and Souza, 2004).

Ultrasound characteristics UH1 and UH2 were also studied in work with common carp (Cyprinus carpio), in which the influence of these regions on FY was verified (Cibert et al., 1999). In another study by Bianchecci (2011), the authors found a similar response with tilapia (O. niloticus), a fact that suggests a strong relation between the muscle portion of these regions and FY in different species, indicating that morphological differentiation influences the definition of the best regions to obtain ultrasound images that are related to FY. This can explain the differentiation of these characteristics (UH1, UH2, and FY), being more clustered (as for the result found for males), or in groups separated from the other morphometric measures (as for the result observed for females), observed in the dendrogram.

The characteristics that showed close or equal impact on the total variation in females and males were corroborated by the spatial projection of the vector ordination (Figure 2), in which several characteristics are visualized in the same quadrant and are practically overlapping. This result 
indicates that some variables have the same impact in explaining the total variation of the data and, in some cases, behave in a practically identical way. This similar behavior can be explained due to the high correlation existing among the characteristics such as BW, FW, and ADG in both sexes. The selection of animals can be directed to the genetic improvement of fillet yield, but it is difficult because it is a trait measured only after slaughter, which makes it important to know its association with other trait(s) that may be obtained without the death of individual candidates for selection. Information associated with this trait that can avoid animal sacrifice is extremely relevant for breeding programs (Turra et al., 2010).

Other researchers (Porto et al., 2015), who evaluated tilapia, also found high association between characteristics, both with genetic information, in which body weight and ADG had a 0.99 correlation and BW association above 0.77, as well as with morphometric information. Oliveira et al. (2016) observed that the high association between characteristics are maintained throughout the generations in genetically improved fish.

Knowing the profile of the variables possible to be obtained makes the collection and data set efficient and low-cost, since it allows to disregard some information known to have low or no influence on the total variation of the data, which can be grouped so closely, saving time, equipment, and labor, without losing accuracy in data analysis.

From the 14 variables present in the dataset for both sexes, it is possible to reduce this value to two and four in females and males, respectively, choosing the characteristics according to the methodology proposed by Jolliffe (2002), in which we can discard as many characteristics as the number of components with a variation of less than $70 \%$. However, the discard of variables and the interpretation of the results must have criteria and caution, and it is not absolutely guaranteed that a chosen subset after the discard of variables can really be the best, since a selected subset in a sample of the present may be are insufficient for analyzes of other samples under future conditions.

In the case of the present study, through the methodology used and the results obtained, we observed that it is possible to reduce the size of the data set without causing a decrease in the precision of the analysis, which is due to the high degree of association found between the variables, as observed with production animals (Yamaki et al., 2009), eliminating redundant information detected through correlation coefficients between characteristics. This analysis has been used to explain structural relationships between animal body measurements and discard of variables, in which most variance components can be discarded.

Considering the results of the principal components (Table 3) to select females, the most relevant (magnitude) characteristics in order of priority are: ADG (PC1), UH1 (PC2), UH2 (PC3), and FY (PC4), which is strengthened by the dendrogram analysis (Figure 1A) and by the relationship between the characteristics (Table 4). It is noticed that in PC4, the W1 characteristic, which is morphometric, indicates that the next component will have more relevant morphometric information. Knowing that $75 \%$ of the data variation can be explained by two PC, the ADG and UH1 characteristics can be used to evaluate and select females. To select males, the most relevant characteristics are: BW (PC1), UH2 (PC2), FY (PC3), and ADG (PC4), corresponding to the four PC explaining $72 \%$ of the data variation (Table 3), and both cluster analysis (Figure 1) and correlation analysis (Table 4) corroborate these results.

The main component analysis is a statistical approach, which can be used to analyze the interrelationships between variables by condensing the information contained in them into one smaller set of statistical variables, with minimal loss of information, minimizing redundancies. The analysis of clusters is a classification technique typology of data that considers the similarity between the observed characteristics, calculated based on a distance, in which the elements with closest Euclidean distances are being grouped sequentially to a single group to be formed. The results can easily be graphically displayed in diagrams called dendrograms; in this way, working with both methodologies can strengthen the results found, as well as facilitate understanding.

R. Bras. Zootec., 48:e20170179, 2019 
For the genetic improvement of fish, the analysis of main components can act as a tool, helping breeders to choose the most relevant variables to be used in breeding programs (Cruz et al., 2004), since this methodology allows judging the importance of available variables in a more productive, fast, objective, and efficient way, separating the important information from the redundant and random ones.

\section{Conclusions}

The most relevant characteristics for the selection of breeders with higher productive performance are the average daily gain for females and body weight for males, and ultrasound information may aid in selection for tilapia breeders. It is possible to reduce the data set of the 14 characteristics used to evaluate both sexes, in only two representing $75 \%$ of the total variation of the data and in four explaining $72 \%$ for females and males, respectively.

\section{References}

Adames, M. S.; Krause, R. A.; Damasceno, D. Z.; Piana, P. A.; Oliveira, J. D. S. O. and Bombardelli, R. A. 2014. Características morfométricas, rendimentos no processamento e composição centesimal da carne do barbado. Boletim do Instituto de Pesca 40:251-260.

Bianchecci, D. C. 2011. Predição do peso e do rendimento de filé de tilápia do Nilo a partir de medidas ultrassonográficas e morfométricas, e validação dos modelos de regressão. Dissertação (M.Sc.). Universidade Estadual do Oeste do Paraná, Marechal Cândido Rondon.

Bombardelli, R. A.; and Sanches, E. A. 2008. Avaliação das características morfométricas corporais, do rendimento de cortes e composição centesimal da carne do armado (Pterodoras granulosus). Boletim do Instituto de Pesca 34:221-229.

Cibert, C.; Fermon, Y.; Vallod, D. and Meunier, F. J. 1999. Morphological screening of carp Cyprius carpio: relationship between morphology and fillet yield. Aquatic Living Resources 12:1-10. https://doi.org/10.1016/ S0990-7440(99)80009-6

Cruz, C. D.; Regazzi, A. J. and Carneiro, P. C. S. 2004. Divergência genética. p.377-413. In: Modelos biométricos aplicados ao melhoramento. Cruz, C. D.; Regazzi, A. J. and Carneiro, P. C. S., eds. UFV, Viçosa, MG.

Eyo, A. A. 1993. Carcass composition and filleting yield of ten fish species from Kainji Lake: proceedings of the FAO expert consultation on fish technology in Africa. FAO Fisheries Report 467. p.173-175.

FAO - Food and Agriculture Organization of the United Nations. 2014. FAO yearbook: Fishery and Aquaculture Statistics. FAO, Rome, Italy.

IBGE - Instituto Brasileiro de Geografia e Estatística. 2016. Produção Pecuária Municipal. 28p.

Jolliffe, I. T. 2002. Principal component analysis. 2nd ed. Springer, New York.

Kunita, N. M.; Oliveira, C. A. L.; Oliveira, S. N.; Yoshida, G. M.; Rizzato, G. S.; Resende, E. K. and Ribeiro, R. P. 2013. Avaliação genética de características morfométricas em tilapias do Nilo cultivadas. Archivos de Zootecnia 62:555-566. https://doi.org/10.4321/S0004-05922013000400008

Macedo-Viégas, E. M. and Souza, M. L. R. 2004. Pré-processamento e conservação do pescado produzido em piscicultura. p.405-480. In: Tópicos especiais em piscicultura de água doce tropical intensiva. Cyrino, J. E. P.; Urbinati, E. C.; Fracalossi, D. M. and Castagnolli, N., eds. TecArt, São Paulo.

Manly, B. F. J. 2008. Métodos estatísticos multivariados: uma introdução. 3.ed. Bookman, Porto Alegre.

Oliveira, C. A. L.; Ribeiro, R. P.; Yoshida, G. M.; Kunita, N. M.; Rizzato, G. S.; Oliveira, S. N.; Santos, A. I. and Nguyen, H. N. 2016. Correlated changes in body shape after five generations of selection to improve growth rate in a breeding program for Nile tilapia Oreochromis niloticus in Brazil. Journal of Applied Genetics 57:487-493. https://doi.org/10.1007/s13353-016-0338-5

Oksanen, J.; Blanchet, F. G.; Kindt, R.; Legendre, P.; O’Hara, R. G.; Simpson, G. L.; Solymos, P.; Henry, M.; Stevens, H. and Wagner, H. 2010. Vegan: Community Ecology Package. R package version 1.17-0. Available at: <http://CRAN.R-project. org/package=vegan>. Accessed on: Jan. 3, 2015.

Porto, E. P.; Oliveira, C. A. L.; Martins, E. N.; Ribeiro, R. P.; Conti, A. C. M.; Kunita, N. M.; Oliveira, S. N. and Porto, P. P. 2015. Resposta à seleção de características de desempenho em tilápia-do-nilo. Pesquisa Agropecuária Brasileira 50:745-752. https://doi.org/10.1590/S0100-204X2015000900002

Pinheiro, L. M. S.; Martins, R. T.; Pinheiro, L. A. S. and Pinheiro, L. E. L. 2006. Rendimento industrial de filetagem da tilápia tailandesa (Oreochromis spp.). Arquivo Brasileiro de Medicina Veterinária e Zootecnia 58:257-262. https://doi.org/10.1590/S0102-09352006000200015

R. Bras. Zootec., 48:e20170179, 2019 
R Development Core Team. 2008. R: A language and environment for statistical computing. R Foundation for Statistical Computing, Vienna, Austria.

Resende, E. K.; Oliveira, C. A. L.; Legat, A. P. and Ribeiro, R. P. 2010. Melhoramento animal no Brasil: uma visão crítica. Espécies aquáticas. In: Anais do 8o Simpósio Brasileiro de Melhoramento Animal. Sociedade Brasileira de Melhoramento Animal, Maringá.

Ribeiro, R. P. and Legat, A. P. 2008. Delineamento de programas de melhoramento genético de espécies aquícolas no Brasil. Embrapa Meio-Norte, Teresina.

Silva, C. S. and Sbrissia, A. F. 2010. Análise de componentes principais entre características morfogênicas e estruturais em capim-marandu sob lotação contínua. Ciência Rural 40:690-693. https://doi.org/10.1590/S0103-84782010000300034

Silva, F. V.; Soares, F. D. S.; Oliveira, L. L. S.; Toral, F. L. B.; Reis, S. T.; Alves, D. D.; Rocha Júnior, V. R. and Gomes, R. R. R. 2015. Componentes principais das características de carcaças de bovinos anelorados e fontes de variação de lesões. Pesquisa Veterinária Brasileira 35:148-152. https://doi.org/10.1590/S0100-736X2015000200009

Souza, A. M. 2000. Monitoração e ajuste de realimentação em processos produtivos multivariados. Tese (D.Sc.). Universidade Federal Santa Catarina, Florianópolis.

Turra, E. M.; Oliveira, D. A. A.; Teixeira, E. A.; Prado, S. A.; Melo, D. C. and Sousa, A. B. 2010. Uso de medidas morfométricas no melhoramento genético do rendimento do filé da tilápia do Nilo (Oreochromis niloticus). Revista Brasileira de Reprodução Animal 34:29-36.

Yamaki, M.; Menezes, G. R. O.; Paiva, A. L. C.; Barbosa, L.; Silva, R. F.; Teixeira, R. B.; Torres, R. A. and Lopes, P. S. 2009. Estudo de características de produção de matrizes de corte por meio da análise de componentes principais. Arquivo Brasileiro de Medicina Veterinária e Zootecnia 61:227-231. https://doi.org/10.1590/S0102-09352009000100032 